\title{
Morbi-mortality of lower respiratory tract infections in Spain, 1997-2018
}

\author{
Morbimortalidad de las infecciones del tracto respiratorio \\ inferior en España, 1997-2018
}

https://doi.org/10.23938/ASSN.0962

L. Leache ${ }^{1}$, M. Gutiérrez-Valencia ${ }^{1}$, L.C. Saiz ${ }^{1}$, J. Erviti ${ }^{2}$

\begin{abstract}
Background. Lower respiratory tract infections (LRTIs) are one of the leading causes of infectious disease mortality worldwide. The aims of the study were to determine the incidence of hospitalizations due to LRTIs, and to analyze the clinical outcomes of the hospitalized patients.

Methods. An observational study of hospitalizations due to LRTIs (pneumonia and acute bronchitis/bronchiolitis) in Spain from 1997 to 2018 was carried out. Data were extracted from the national information system for hospital data.

Results. Overall, $3.5 \%$ (IQR: $3.4-3.5 \%$ ) of total hospitalizations were caused by LRTIs, with a median incidence of 31.2 (IQR: 27.8-33.0) per 10,000 inhabitants/year. The median incidence was higher for pneumonia than for acute bronchitis/bronchiolitis cases (22.2; IQR: 19.1-23.5 vs. 9.0; IQR: 8.4-9.6 per 10,000 inhabitants/year; $\mathrm{p}<0.001$ ) and increased by $65.7 \%$ from 1997 to 2018 . A $41.2 \%$ of the hospitalizations due to LRTIs took place amongst people over 74 years. The median length of stay was 8.9 days (IQR: 7.6-10.4) and was higher for hospitalizations due to pneumonia than for acute bronchitis/bronchiolitis (9.5 days; IQR: 8.3-10.6 vs. 5.7; IQR: 5.5-6.2; $\mathrm{p}<0,001)$. In $89.1 \%$ of total hospitalizations due to LRTIs, patients were discharged home. In-hospital mortality was $6.8 \%$, with 9,380 deaths (IQR: 8,192-10,157) per year. Mortality was higher for pneumonia (9.0 vs. $1.7 \% ; \mathrm{p}<0.001)$ and doubled from 1997 to 2018 (5,257 deaths in 1997 and 10,514 in 2018). A $75.5 \%$ of the deaths occurred amongst people over 74 years.
\end{abstract}

Conclusions. LRTIs are associated with a high morbi-mortality in Spain. Effective measures that can contribute towards the prevention and treatment of LRTIs need to be adopted.

Keywords. Respiratory tract infections. Pneumonia. Hospitalization. Mortality

\section{RESUMEN}

Fundamento. Las infecciones del tracto respiratorio inferior (ITRI) constituyen una de las principales causas de mortalidad por enfermedades infecciosas a nivel mundial Los objetivos del estudio consistieron en determinar la incidencia de hospitalizaciones por ITRI, y en analizar los resultados clínicos de los pacientes hospitalizados.

Métodos. Se llevó a cabo un estudio observacional de las hospitalizaciones por ITRI (neumonía y bronquitis/bronquiolitis aguda) en España entre 1997-2018. Los datos se extrajeron del Registro Español de Atención Sanitaria Especializada.

Resultados. El 3,5\% (RIC: 3,4-3,5\%) del total de hospitalizaciones se debieron a ITRI, con una incidencia mediana de 31,2 (RIC: $27,8-33,0$ ) por cada 10.000 habitantes/año. La mediana de incidencia fue superior para las neumonías que para las bronquitis/bronquiolitis agudas (22,2; RIC: 19,1-23,5 vs. 9,0; RIC: 8,4-9,6 por 10.000 habitantes/año; $\mathrm{p}<0,001$ ), y entre $1997-2018$ aumentó un $65,7 \%$. Un $41,2 \%$ de las hospitalizaciones por ITRI ocurrieron en mayores de 74 años. La mediana de duración de las hospitalizaciones por ITRI fue 8,9 días (RIC: 7,6-10,4), superior para neumonías (9,5 días; RIC: 8,3-10,6 vs. 5,7; RIC: 5,5-6,2; $\mathrm{p}<0,001)$. En un $89,1 \%$ de las hospitalizaciones por ITRI los pacientes fueron dados de alta a domicilio. La mortalidad intrahospitalaria fue $6,8 \%$, con 9.380 fallecimientos anuales (RIC: $8,192-10,157)$. La mortalidad fue superior para neumonías ( 9,0 vs. $1,7 \% ; \mathrm{p}<0,001)$ y se duplicó entre 1997 y 2018 (5.257 fallecimientos en 1997 y 10.514 en 2018). El 75,5\% de las muertes ocurrieron en mayores de 74 años.

Conclusiones. Las ITRI se asocian a una elevada morbimortalidad. Se requieren medidas efectivas para su prevención y tratamiento.

Palabras clave. Infecciones del tracto respiratorio. Neumonía. Hospitalización. Mortalidad.
1. Unit of Innovation and Organization. Navarre Health Service. Pamplona. Spain.

2. Therapeutics Initiative. Department of Anesthesiology, Pharmaceuticals and Therapeutics. University of British Columbia. Vancouver. Canada.

Received: November, 25, 2020

Revised: February, 10, 2021

Accepted: March, 31, 2021
Corresponding author:

Leire Leache

Unit of Innovation and Organization

Navarre Health Service

Tudela 20, $1^{\text {st }}$ floor

31003 Pamplona

Spain

E-mail: lleachea@navarra.es 


\section{INTRODUCTION}

Lower respiratory tract infections (LRTIs) are defined as diseases of the lower airways, and include pneumonia and bronchiolitis ${ }^{1}$. These types of infections represent a substantial and growing cause for public health concern even further in the current context of the COVID-19 pandemic. LRTIs remained the fourth leading cause of years of life lost worldwide, causing 1,515 age-standardised years of life lost per 100,000 people and $2,558,600$ deaths in $2017^{2}$. Globally, deaths from LRTIs decreased by $36.4 \%$ between 2007 and 2017 for children younger than 5 years, while a $33.6 \%$ increase occurred among older adults ( $\geq 70$ years) $)^{2}$.

Morbidity and mortality associated with LRTIs differ among countries depending on the socio-economic situation, health conditions, nutritional status, and access to health care and resources, among others $^{1}$. Understanding and quantifying trends in LRTIs in our setting is crucial to enable individualized measures and interventions to be developed that can reduce the LRTI burden, and to identify people at a higher risk of suffering complications. Some studies have been carried out to analyze community- and hospital-acquired pneumonia data from Spain ${ }^{3-7}$. However, to date the morbi-mortality of overall LRTIs in Spain has not been reported.

The objectives of the study were to determine the incidence of hospitalizations due to LRTIs over time, and to analyze the clinical outcomes of the hospitalized patients according to patients' characteristics, and also differentiating by the main clinical diagnosis.

\section{METHODS}

An observational descriptive study was conducted to analyze hospitalizations in acute care hospitals in Spain from 1997 to 2018 (both inclusive). All the data for the study were extracted from the national information system for hospital data in Spain [Conjunto Mínimo Básico de DatosHospitalización (CMBD-H) and Registro de Atención Especializada (RAE-CMBD)], which includes aggregated and anonymized data from both public and private hospitals $^{8}$. The database was established in 1997, is freely accessible and is managed by the Health Information General Sub-Directorate of the Spanish Ministry of Health, Consumer Affairs and Social Welfare. In 2017 the database included information from $96 \%$ of all the acute care hospitals in Spain ${ }^{8}$. Data for the study were extracted in November 2019 and updated in February 2021.

The study focused on hospitalizations in acute care hospitals in which LRTIs (pneumonia and acute bronchitis/bronchiolitis) were registered as the primary diagnosis. The primary diagnosis refers to the diagnosis established by the attending physician as the main cause of hospitalization. Hospitalizations in which LRTIs were recorded as secondary diagnoses were not included in the study since they refer to clinical events that occur during the patient's hospital stay, and therefore do not constitute the cause of hospitalization.

Diagnoses are registered at hospital discharge and codified according to the Ninth and Tenth Revisions of the International Classification of Disease (ICD-9 and ICD$10)^{9,10}$. The ICD-9 and ICD-10 codes for LRTIs included in this study are shown in appendix 1.

Collected data included hospitalizations due to LRTIs of any type (also differentiating by the specific diagnosis: pneumonia and acute bronchitis/bronchiolitis), attending medical service (data available for the period 2005-2018), sex and age distribution of the hospitalized patients $(<1$ year-old, 1-14, 15-44, 45-64, 65-74, >74 years), length of hospital stay (days), and type of hospital discharge (home, exitus, transfer to another hospital, transfer to a residential centre, voluntary discharge, other or unknown).

The number of hospitalizations from all causes during the study period was extracted to determine the proportion of hospitalizations due to LRTIs out of total hospitalizations, and was not used for any other purposes.

The annual incidence rate of hospitalizations, which referred to the number of 
hospital discharges per 10,000 inhabitants and year, and the annual proportion of hospitalizations due to LRTIs with respect to hospitalization from all causes in the period 1997-2018 were estimated. Length of hospital stay and type of hospital discharge, specifically mortality, were analyzed. Timetrend distribution of the included variables was described. Data were also analyzed according to the primary diagnosis (pneumonia vs. acute bronchitis/bronchiolitis), patients' characteristics and attending medical service.

Secondly, data for hospitalizations due to LRTIs registered as a primary diagnosis (included in the study) and for hospitalizations with LRTIs recorded either as a primary or secondary diagnosis for the same time-period were compared to analyze the risk of bias.

Data were analyzed using STATA version 13.0. Normality of variables was analyzed using Shapiro-Wilk test. Categorical variables were expressed using absolute and relative frequency, and continuous variables were expressed using median and interquartile range (IQR). Variables were compared between the different diagnoses (pneumonia vs. acute bronchitis/bronchiolitis), sex and age range using Chi-square for categorical data and Mann-Whitney U test for continuous variables.

\section{RESULTS}

A total of $85,459,228$ hospitalizations from all causes were reported from 1997 to 2018 , with a median of $4,122,869$ (IQR: $3,343,711-4,352,746)$ hospitalizations per year. Hospitalizations due to LRTIs during the same time period were $2,952,336$ (70.6\% pneumonia, $29.4 \%$ acute bronchitis/bronchiolitis), with a median of 142,383 (IQR: $112,667-152,242)$ hospitalizations per year. The median annual proportion of hospitalizations due to LRTIs was 3.5\% (IQR:3.4-3.5\%) of total hospitalizations from all causes. The annual proportion of hospitalizations due to pneumonia was significantly higher than for hospitalizations due to acute bronchitis/ acute bronchiolitis (median: 2.4\%; IQR: 2.4$2.5 \%$ vs. $1.0 \%$; IQR: $1.0-1.1 ; \mathrm{p}<0.001$ ).

The temporal trend of the annual incidence rate of hospitalizations due to LRTIs is shown in table 1 and figure 1. Overall, there was an upward trend from 1997. The annual incidence rate increased by $65.7 \%$ in 2018 as compared to 1997 (from 21.3 per 10,000 inhabitants and year in 1997 to 35.3 per 10,000 inhabitants and year in 2018). The lowest rate was in 1997 (21.3 per 10,000 inhabitants), whereas the highest rate was in 2015 (37.03 per 10,000 inhabitants and year). In this year, the incidence seems higher than expected when compared to near years.

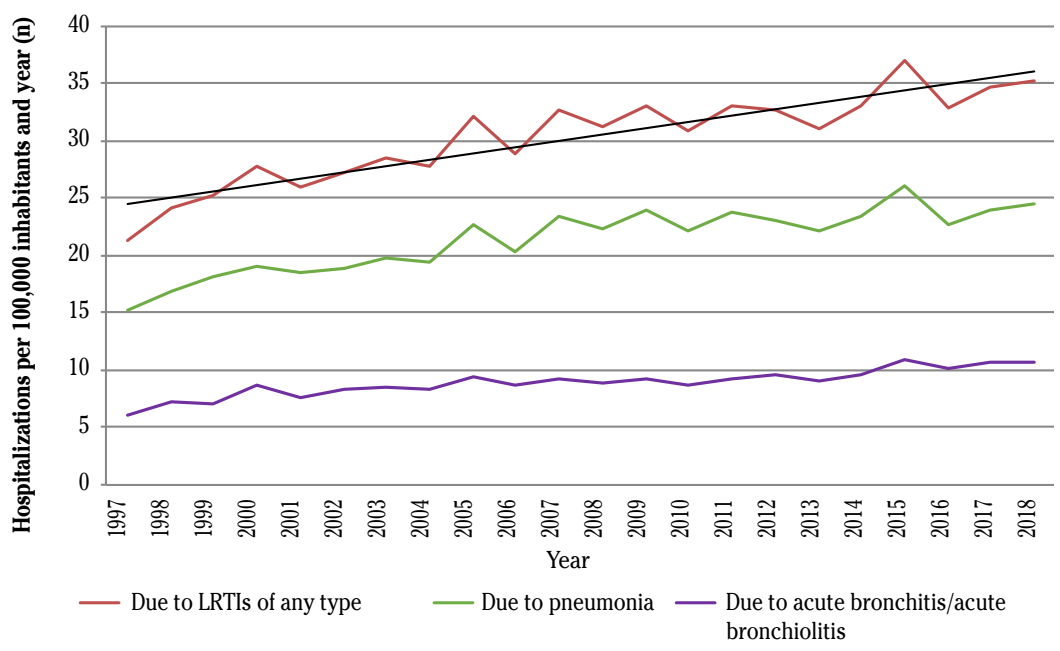

Figure 1. Temporal trend of the annual incidence rate of hospitalizations due to lower respiratory tract infections (LRTIs). 
Table 1. Time-trend distribution of hospitalizations due to lower respiratory tract infections (LRTIs) according to different variables

\begin{tabular}{lcccccccccccc}
\hline Variables & $\mathbf{1 9 9 7 -}$ & $\mathbf{1 9 9 9 -}$ & $\mathbf{2 0 0 1 -}$ & $\mathbf{2 0 0 3 -}$ & $\mathbf{2 0 0 5 -}$ & $\mathbf{2 0 0 7 -}$ & $\mathbf{2 0 0 9 -}$ & $\mathbf{2 0 1 1 -}$ & $\mathbf{2 0 1 3 -}$ & $\mathbf{2 0 1 5 -}$ & $\mathbf{2 0 1 7 -}$ & Total \\
& $\mathbf{1 9 9 8}$ & $\mathbf{2 0 0 0}$ & $\mathbf{2 0 0 2}$ & $\mathbf{2 0 0 4}$ & $\mathbf{2 0 0 6}$ & $\mathbf{2 0 0 8}$ & $\mathbf{2 0 1 0}$ & $\mathbf{2 0 1 2}$ & $\mathbf{2 0 1 4}$ & $\mathbf{2 0 1 6}$ & $\mathbf{2 0 1 8}$ & \\
\hline Incidence $^{*}$, & 22.7 & 26.5 & $26.6(26.0-$ & 28.1 & 30.5 & 31.9 & 32.0 & 32.8 & 32.1 & 34.9 & 35.0 & 31.2 \\
median $(\mathrm{IQR})$ & $(21.3-24.1)$ & $(25.2-27.8)$ & $27.3)$ & $(27.8-28.4)$ & $(29.0-32.1)$ & $(31.2-32.6)$ & $(30.9-33.1)$ & $(32.7-33.0)$ & $(31.1-33.1)$ & $(32.9-37.0)$ & $(34.7-35.3)$ & $(27.8-33.0)$ \\
\hline
\end{tabular}

\section{Main cause of hospitalization ${ }^{\text {a }}$}

\begin{tabular}{|c|c|c|c|c|c|c|c|c|c|c|c|c|}
\hline $\begin{array}{l}\text { LRTIs of any } \\
\text { type, } n \text {. }\end{array}$ & 180,107 & 212,681 & 218,501 & 238,421 & 266,855 & 288,767 & 294,652 & 303,183 & 298,617 & 324,496 & 326,056 & $2,952,336$ \\
\hline Pneumonia, \% & 70.7 & 70.1 & 70.1 & 69.9 & 70.3 & 71.7 & 72.0 & 71.4 & 70.9 & 69.9 & 69.5 & 70.6 \\
\hline $\begin{array}{l}\text { Acute bronchitis/ } \\
\text { bronchiolitis, \% }\end{array}$ & 29.3 & 29.9 & 29.9 & 30.1 & 29.7 & 28.3 & 28.0 & 28.6 & 29.1 & 30.1 & 30.5 & 29.4 \\
\hline
\end{tabular}

\begin{tabular}{|c|c|c|c|c|c|c|c|c|c|c|c|c|}
\hline \multicolumn{13}{|l|}{$\mathbf{S e x}^{\mathbf{b}}, \%$} \\
\hline Male & 59.9 & 59.3 & 60.1 & 59.3 & 58.7 & 57.8 & 57.4 & 56.8 & 56.3 & 54.7 & 53.1 & 57.3 \\
\hline Female & 40.1 & 40.6 & 39.9 & 40.7 & 41.3 & 42.2 & 42.6 & 43.1 & 43.7 & 45.3 & 46.9 & 42.7 \\
\hline \multicolumn{13}{|l|}{ Age, years, \% } \\
\hline$<1$ & 15.7 & 14.4 & 16.0 & 15.2 & 14.1 & 12.9 & 12.7 & 13.0 & 11.7 & 12.2 & 12.0 & 13.4 \\
\hline $1-14$ & 16.5 & 13.2 & 14.6 & 13.2 & 13.7 & 13.1 & 13.6 & 11.8 & 10.9 & 10.3 & 10.1 & 12.5 \\
\hline $15-44$ & 8.5 & 7.8 & 8.1 & 7.5 & 7.2 & 7.5 & 7.5 & 5.7 & 5.4 & 5.1 & 5.1 & 6.7 \\
\hline $45-64$ & 12.4 & 12.6 & 11.6 & 11.6 & 11.6 & 12.2 & 12.0 & 11.4 & 12.0 & 11.6 & 12.1 & 11.9 \\
\hline $65-74$ & 16.9 & 18.0 & 16.3 & 16.1 & 15.0 & 13.8 & 12.8 & 12.4 & 13.0 & 12.9 & 13.1 & 14.3 \\
\hline$>74$ & 29.9 & 34.1 & 33.4 & 36.5 & 38.5 & 40.5 & 41.4 & 45.6 & 47.1 & 47.9 & 47.6 & 41.2 \\
\hline \multicolumn{13}{|c|}{ Attending medical service, $\%$} \\
\hline Internal Medicine & NR & NR & NR & NR & 35.0 & 41.8 & 44.1 & 45.5 & 47.3 & 47.5 & 48.2 & 44.5 \\
\hline Paediatrics & NR & NR & NR & NR & 23.0 & 24.6 & 25.6 & 23.9 & 21.9 & 21.8 & 21.5 & 23.1 \\
\hline Pneumology & NR & NR & NR & NR & 15.3 & 15.7 & 16.4 & 15.9 & 16.8 & 16.0 & 15.2 & 15.9 \\
\hline Geriatrics & NR & NR & NR & NR & 1.6 & 1.3 & 2.1 & 2.3 & 2.7 & 3.0 & 3.1 & 2.4 \\
\hline Medical Oncology & NR & NR & NR & NR & 1.2 & 1.4 & 1.5 & 1.7 & 1.8 & 1.6 & 1.8 & 1.6 \\
\hline $\begin{array}{l}\text { Clinical } \\
\text { Haematology }\end{array}$ & NR & NR & NR & NR & 1.0 & 1.1 & 1.1 & 1.1 & 1.1 & 1.1 & 1.1 & 1.1 \\
\hline $\begin{array}{l}\text { Infectious } \\
\text { Diseases }\end{array}$ & NR & NR & NR & NR & 0.8 & 0.9 & 1.1 & 1.2 & 1.1 & 1.2 & 1.2 & 1.1 \\
\hline $\begin{array}{l}\text { Anaesthesia, } \\
\text { Resuscitation } \\
\text { and Intensive } \\
\text { Care Services }\end{array}$ & NR & NR & NR & NR & 0.9 & 0.9 & 0.8 & 0.8 & 0.7 & 0.6 & 0.7 & 0.8 \\
\hline Other & NR & NR & NR & NR & 21.2 & 12.4 & 7.3 & 7.5 & 6.5 & 7.3 & 7.4 & 9.7 \\
\hline $\begin{array}{l}\text { Length of hospital } \\
\text { stay, median (IQR) }\end{array}$ & $\begin{array}{c}9.8 \\
(7.8-10.5)\end{array}$ & $\begin{array}{c}9.9 \\
(8.0-11.5)\end{array}$ & $\begin{array}{c}9.7 \\
(8.2-11.3)\end{array}$ & $\begin{array}{c}9.7 \\
(8.1-11.1)\end{array}$ & $\begin{array}{c}9.4 \\
(7.8-10.7)\end{array}$ & $\begin{array}{c}8.7 \\
(8.0-10.7)\end{array}$ & $\begin{array}{c}8.5 \\
(7.5-9.9)\end{array}$ & $\begin{array}{c}8.4 \\
(7.3-9.2)\end{array}$ & $\begin{array}{c}8.3 \\
(7.8-9.1)\end{array}$ & $\begin{array}{c}8.2 \\
(7.1-8.8)\end{array}$ & $\begin{array}{c}8.1 \\
(6.5-9.2)\end{array}$ & $\begin{array}{c}8.9 \\
(7.6-10.4)\end{array}$ \\
\hline Mortality, n (\%) & $\begin{array}{c}11,736 \\
(6.5)\end{array}$ & $\begin{array}{c}15,455 \\
(7.3)\end{array}$ & $\begin{array}{c}15,454 \\
(7.1)\end{array}$ & $\begin{array}{c}17,369 \\
(7.3)\end{array}$ & $\begin{array}{c}18,989 \\
(7.1)\end{array}$ & $\begin{array}{c}18,759 \\
(6.5)\end{array}$ & $\begin{array}{c}19,244 \\
(6.5)\end{array}$ & $\begin{array}{c}21,487 \\
(7.1)\end{array}$ & $\begin{array}{c}20,066 \\
(6.7)\end{array}$ & $\begin{array}{c}21,698 \\
(6.7)\end{array}$ & $\begin{array}{c}21,257 \\
(6.5)\end{array}$ & $\begin{array}{c}201,514 \\
(6.8)\end{array}$ \\
\hline
\end{tabular}

*: /10,000 inhabitants; IQR: interquartile range; a: $\mathrm{p}<0.001$ for the comparison between pneumonia and acute bronchitis/bronchiolitis; b: $\mathrm{p}<0.001$ for the comparison between males and females; NR: not reported.

When the entire study period is considered, the median annual incidence rate of hospitalizations due to LRTIs was 31.2 (IQR: 27.8-33.0) per 10,000 inhabitants and year (Table 1). It was significantly higher for hospitalizations due to pneumonia than for hospitalizations due to acute bronchitis/ bronchiolitis (22.2; IQR: 19.1-23.5 per 10,000 inhabitants and year vs. 9.0; IQR: 8.4-9.6 per 10,000 inhabitants and year; $\mathrm{p}<0.001$ ).

Men accounted for a higher number of hospitalizations due to LRTIs than women (57.3 vs. $42.7 \% ; \mathrm{p}<0.001$ ). Around half of the hospitalizations due to LRTIs occurred 
in people over 74 years of age (41.2\%). Internal Medicine was the attending medical service in most cases, followed by Paediatrics and Pneumology (Table 1).

Table 2 describes hospitalizations, distinguishing between those caused by pneumonia and those caused by acute bronchitis/bronchiolitis. Statistically significant differences were found between both clinical situations in sex, age and attending medical service. Most of the hospitalizations due to pneumonia corresponded to people over 74 years of age $(47.1 \%)$. In contrast, hospitalizations due to acute bronchitis/bronchiolitis were more frequent in people under one year $(40.7 \%)$, followed by people over 74 years $(27.1 \%)$.
When analyzing hospitalizations due to LRTIs that were recorded either as a primary or secondary diagnosis, the distribution according to the clinical diagnosis (pneumonia vs. acute bronchitis/bronchiolitis), sex and age matched those corresponding to hospitalizations with LRTIs as primary diagnosis, which contributed to $67.9 \%$ of all hospitalizations (Appendix 2).

The median length of stay declined over time (from 9.8 days; IQR: 7.8-10.5 in 19971998 to 8.1 days, IQR: $6.5-9.2$ in 2017-2018) (Table 1, Fig. 2). The median length of stay in hospitalizations due to LRTIs was 8.9 days (IQR: 7.6-10.4) (Table 1), and was significantly higher for hospitalizations due to pneumonia than for hospitalizations

Table 2. Distribution of hospitalizations due to lower respiratory tract infections (LRTIs) overall and according to the main cause of hospitalization

\begin{tabular}{|c|c|c|c|c|}
\hline \multirow[b]{2}{*}{ Variables } & \multicolumn{4}{|c|}{ Main cause of hospitalization } \\
\hline & $\begin{array}{c}\text { LRTIs } \\
\text { of any type }\end{array}$ & Pneumonia & $\begin{array}{l}\text { Acute bronchitis/ } \\
\text { bronchiolitis }\end{array}$ & $\mathbf{p}^{\mathbf{a}}$ \\
\hline $\mathbf{N}(\%)$ & $\begin{array}{c}2,952,336 \\
(100)\end{array}$ & $\begin{array}{l}2,084,650 \\
(70.6)\end{array}$ & $\begin{array}{c}867,686 \\
(29.4)\end{array}$ & - \\
\hline \multicolumn{5}{|l|}{ Sex, \% } \\
\hline Males & 57.3 & 60.1 & 50.5 & $<0.001$ \\
\hline Females & 42.7 & 39.9 & 49.5 & $<0.001$ \\
\hline \multicolumn{5}{|l|}{ Age, years, \% } \\
\hline$<1$ & 13.4 & 2.0 & 40.7 & $<0.001$ \\
\hline $1-14$ & 12.5 & 11.4 & 15.3 & $<0.001$ \\
\hline $15-44$ & 6.7 & 8.2 & 3.0 & $<0.001$ \\
\hline $45-64$ & 11.9 & 14.4 & 6.0 & $<0.001$ \\
\hline $65-74$ & 14.3 & 16.9 & 7.9 & $<0.001$ \\
\hline$>74$ & 41.2 & 47.1 & 27.1 & $<0.001$ \\
\hline \multicolumn{5}{|c|}{ Attending medical service $(2005-2018)^{\mathrm{b}}, \%$} \\
\hline Internal Medicine & 44.5 & 51.9 & 26.5 & $<0.001$ \\
\hline Paediatrics & 23.1 & 11.7 & 50.8 & $<0.001$ \\
\hline Pneumology & 15.9 & 19.4 & 7.3 & $<0.001$ \\
\hline Geriatrics & 2.4 & 2.9 & 0.9 & $<0.001$ \\
\hline Medical Oncology & 1.6 & 1.9 & 0.7 & $<0.001$ \\
\hline Clinical Haematology & 1.1 & 1.4 & 0.4 & $<0.001$ \\
\hline Infectious Diseases & 1.1 & 1.4 & 0.3 & $<0.001$ \\
\hline $\begin{array}{l}\text { Anaesthesia, Resuscitation and } \\
\text { Intensive Care Services }\end{array}$ & 0.8 & 0.9 & 0.3 & $<0.001$ \\
\hline Other & 9.7 & 8.5 & 12.7 & $<0.001$ \\
\hline
\end{tabular}

a: comparison between hospitalizations due to pneumonia and hospitalizations due to acute bronchitis/bronchiolitis; b: data correspond to hospitalizations for the period 2005-2018: $n=2,102,626$ hospitalizations due to LRTIs; $1,488,469$ $(70.8 \%)$ due to pneumonia and 614,157 (29.2\%) due to acute bronchitis/bronchiolitis. 
Table 3. Length of hospital stay, type of hospital discharge and mortality among hospitalizations due to lower respiratory tract infections (LRTIs)

\begin{tabular}{|c|c|c|c|c|}
\hline \multirow[b]{2}{*}{ Variables } & \multicolumn{3}{|c|}{ Main cause of hospitalization } & \multirow[b]{2}{*}{$\mathbf{p}^{\mathbf{a}}$} \\
\hline & $\begin{array}{l}\text { LRTIs of any type } \\
\quad(\mathrm{n}=2,952,336)\end{array}$ & $\begin{array}{c}\text { Pneumonia } \\
(\mathrm{n}=2,084,650)\end{array}$ & $\begin{array}{c}\text { Acute bronchitis/ } \\
\text { bronchiolitis } \\
(\mathrm{n}=867,686)\end{array}$ & \\
\hline Length of hospital stay*, median (IQR) & $8.9(7.6-0.4)$ & $9.5(8.3-10.6)$ & $5.7(5.5-6.2)$ & $<0.001$ \\
\hline \multicolumn{5}{|l|}{ Type of discharge, $\%$} \\
\hline Home & 89.1 & 86.8 & 94.7 & $<0.001$ \\
\hline In-hospital mortality & 6.8 & 9.0 & 1.7 & $<0.001$ \\
\hline Transfer to another hospital & 2.0 & 2.0 & 1.9 & $<0.001$ \\
\hline Transfer to a residential centre & 0.9 & 0.9 & 0.8 & $<0.001$ \\
\hline Voluntary discharge & 0.4 & 0.5 & 0.4 & $<0.001$ \\
\hline Others or unknown & 0.8 & 0.8 & 0.7 & $<0.001$ \\
\hline In-hospital mortality, n (\%) & $201,514(6.8)$ & $186,989(9.0)$ & $14,525(1.7)$ & $<0.001$ \\
\hline \multicolumn{5}{|l|}{ Sex, \%: } \\
\hline Male & 59.2 & 60.5 & 42.4 & $<0.001$ \\
\hline Female & 40.8 & 39.5 & 57.6 & $<0.001$ \\
\hline \multicolumn{5}{|l|}{ Age, $\%:$} \\
\hline$\leq 74$ years & 24.5 & 25.0 & 18.5 & $<0.001$ \\
\hline$>74$ years & 75.5 & 75.0 & 81.5 & $<0.001$ \\
\hline \multicolumn{5}{|c|}{ Attending medical service $(2005-2018)^{b}, \%$ : } \\
\hline $\begin{array}{l}\text { Anaesthesia, Resuscitation and } \\
\text { Intensive Care Services }\end{array}$ & 7.9 & - & - & - \\
\hline Geriatrics & 5.7 & - & - & - \\
\hline Clinical Haematology & 1.9 & - & - & - \\
\hline Infectious Diseases & 0.5 & - & - & - \\
\hline Internal Medicine & 61.8 & - & - & - \\
\hline Pneumology & 8.7 & - & - & - \\
\hline Medical Oncology & 4.2 & - & - & - \\
\hline Paediatrics & 0.2 & - & - & - \\
\hline Other & 9.0 & - & - & - \\
\hline
\end{tabular}

*: days; a: comparison between hospitalizations due to pneumonia and hospitalizations due to acute bronchitis/ bronchiolitis; b: data correspond to hospitalizations due to LRTIs that ended in death during the period 2005-2018 $(n=141,500)$.

due to acute bronchitis/bronchiolitis (9.5 days; IQR: 8.3-10.6 vs. 5.7 days; IQR: 5.5-6.2; $\mathrm{p}<0.001$ ) (Table 3). The median length of stay was higher in the subgroup of hospitalizations associated with Anaesthesia, Resuscitation, and Intensive Care services (13.8 days; IQR: 13.0-14.7).

Data related to the type of hospital discharge are presented in table 3 . In $89.1 \%$ of total hospitalizations due to LRTIs, patients returned home after being hospitalized due to LRTIs. In-hospital mortality was $6.8 \%(n=201,514)$, with a median of 9,380 deaths per year (IQR: 8,192-10,157).
Mortality was significantly higher in hospitalizations due to pneumonia (9.0 vs. $1.7 \%$; $\mathrm{p}<0.001$ ). Between 2005 and 2018, 69.2\% of the hospitalizations associated with Anaesthesia, Resuscitation, and Intensive Care services ended in death $(n=11,189$ out of 16,175).

A $75.5 \%$ of the in-hospital deaths occurred in people over 74 years of age. In this age range, $12.5 \%$ of the patients hospitalized due to LRTIs died. Mortality among children under 5 years of age was $0.09 \%$ (635 out of 676,324 ), and was significantly higher for children under one year 


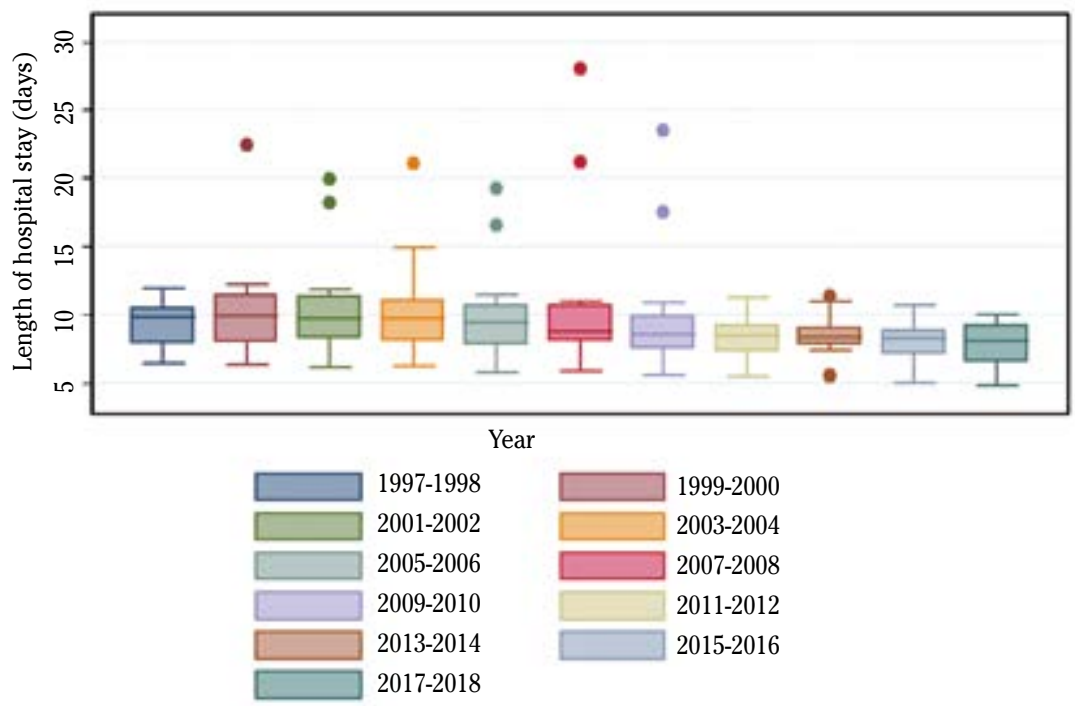

Figure 2. Length of stay in hospitalizations due to lower respiratory tract infections (LRTIs).

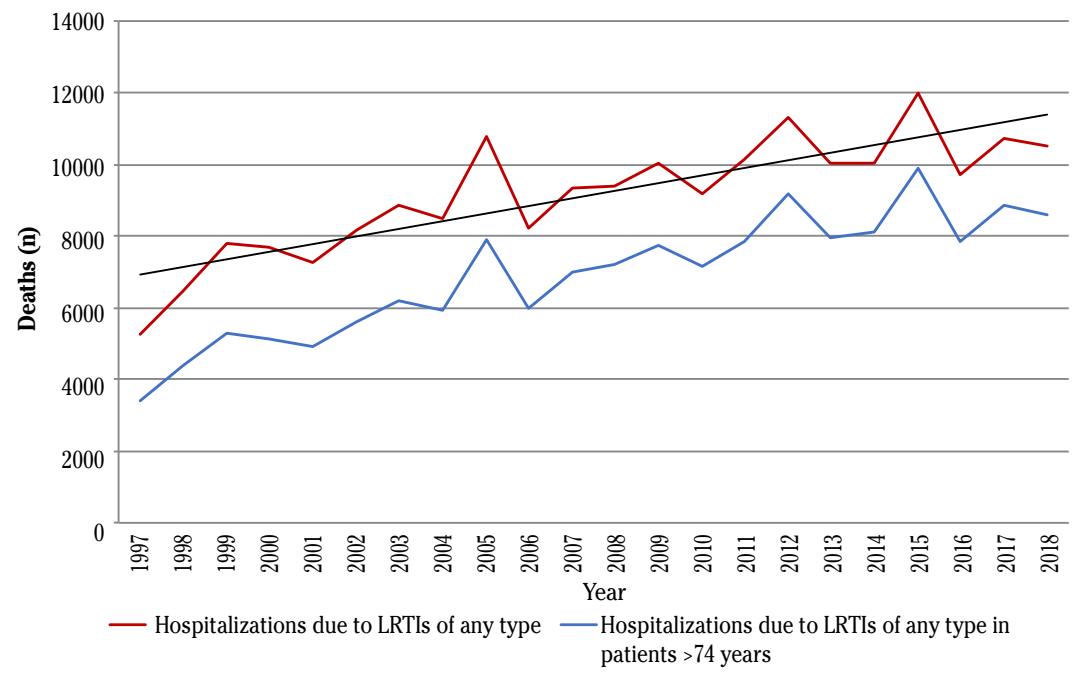

Figure 3. In-hospital mortality during hospitalizations due to lower respiratory tract infections (LRTIs) and in-hospital mortality in the subgroup of patients with more than 74 years.

of age (Appendix 3). Most of the deaths in children under 5 years corresponded to pneumonia cases (57.2\% pneumonia vs. $42.8 \%$ acute bronchitis/bronchiolitis) and mortality rate was significantly higher for pneumonia than for acute bronchitis/bronchiolitis (0.17 vs. $0.06 \%$; $\mathrm{p}$ 0.001).
Deaths during hospitalizations due to LRTIs doubled from 1997 to 2018 (from 5,257 deaths in 1997 to 10,514 in 2018) (Fig. $3)$. However, the proportion of hospitalizations due to LRTIs that ended in death out of total hospitalizations due to LRTIs remained stable (between 6.5-7.3\%) (Table 1). 


\section{DISCUSSION}

We analyzed hospitalizations due to LRTIs in Spain from 1997 to 2018. On average, more than 142,000 hospitalizations due to LRTIs were registered annually and around 9,300 ended in death every year. These data reflect the huge magnitude of this growing problem, which takes on even greater significance globally with the expansion of the SARS-CoV-2 outbreak.

Overall, $71 \%$ of all the hospitalizations due to LRTIs registered during the study period corresponded to pneumonia diagnoses. The pneumonia cases that were acquired during the hospital stay and those who did not require hospital admission should also be added to this figure, since these were not considered in the study. In this regard, both community- and hospital-acquired pneumonia are associated with high morbidity and mortality.

Two reviews that analyzed the burden of community-acquired pneumonia in European adults found that the incidence was higher in individuals aged 65 years or over ${ }^{11,12}$. Similarly, in our study around $40 \%$ of the hospitalizations due to pneumonia occurred in people over 74 years of age.

We found an increasing trend in the number of deaths amongst people hospitalized for LRTIs. These data are in line with the information from The Institute for Health Metrics and Evaluation (IHME), which describes an increase in the deaths related to LRTIs in Spain from 1997 to 2018 (from 23.92 deaths per 100,000 people in 1990 to 29.96 deaths per 100,000 people in 2018$)^{13}$.

In our study, around $76 \%$ of the deaths occurred in people over 74 years of age. These data coincide with the results of a review that reported that mortality attributable to community-acquired pneumonia in Europe was associated with advanced age ${ }^{11}$. The Global Burden of Disease Study 2016 (GBD 2016), which analyzed data regarding LRTIs in 195 countries from 1990-2016, found a high mortality rate in the elderly, with an increase in the number of LRTI deaths among adults of at least 70 years from 2000 to $2016^{1}$. The study obtained an incidence of 267.4 deaths per 100,000 people older than 70 years ( $95 \%$ uncertainty interval: 233.4-289.6) in 2016 ${ }^{1}$. In Spain, according to data from IHME, deaths in people of at least 70 years reached 195.97 per 100,000 people (95\% uncertainty interval: $160.73-222.35)$ in $2018^{13}$.

LRTIs also have major consequences for people at an early age. In our study, mortality among children under 5 years of age hospitalized due to LRTIs was $0.09 \%$ and children under one year were more often affected. Similarly, the GBD 2016 study identified that LRTIs caused $13.1 \%$ (95\% uncertainty interval: 11.8-14.3) of all deaths in children under 5 years of age, most of them occurring in the first year of life ${ }^{1}$. According to our study, although hospitalizations due to acute bronchitis/bronchiolitis were more frequent than pneumonia amongst children under 5 years, mortality was higher with the latter $(0.17 \mathrm{vs}$. $0.06 \%)$.

We found that the length of hospital stay for hospitalizations due to LRTIs was around 9 days, and was longer for pneumonia and for hospitalizations associated with the Anaesthesia, Resuscitation, and Intensive Care Services. People attended by these medical services are more severely ill, and therefore respiratory infections are associated with a high mortality rate, ranging from 15 to $50 \%$ in the case of pneumonia ${ }^{14}$. In our study, $69.2 \%$ of the hospitalizations associated with the Anaesthesia, Resuscitation, and Intensive Care services ended in death according to 2005-2018 data. As a result of the devastating clinical consequences of this setting, a number of evidence based guidelines and recommendations have been published in recent years to prevent and manage hospital-acquired and ventilator-associated pneumonia ${ }^{15-18}$. In addition, several initiatives consisting of multifaceted interventions have been carried out in Intensive Care Units (ICUs) worldwide to tackle the burden of ventilator-associated pneumonia, which showed a positive impact ${ }^{19-20}$.

In Spain, the Pneumonia Zero project was initiated in 2011, which consisted of a nationwide multimodal intervention to prevent ventilator-associated pneumonia in critically ill patients ${ }^{22,23}$. The project was carried out from 2011 to 2012 and included 181 ICUs in Spain ( $75 \%$ of all ICUs in Spain). The adjusted 
incidence density rate of ventilator-associated pneumonia decreased from 9.83 to 4.34 per 1,000 ventilator days after $19-21$ months of intervention ${ }^{23}$.

Our study has some limitations that should be taken into consideration. The national information system for hospital data in Spain progressively incorporated nationwide information, and so information related to hospitalizations in acute care hospitals may be underreported, especially at the beginning of the study period. This issue may have led to an underestimation of the real extent of LRTIs. In addition, only hospitalizations in which LRTIs were established as the main cause of the hospital admission (primary diagnosis) were included in the study. Cases in which LRTIs were not considered as the main cause of the hospitalization were not analyzed. However, a secondary analysis carried out did not show relevant differences when considering hospitalizations with LRTIs registered either as primary or secondary diagnosis. Apart from this, the change in the ICD system that took place in 2016 may have affected the consistency with previous data. Nevertheless, from 2016 onwards hospitalizations continued to show the upward trend seen in previous years. The database used for the study does not include information about the patients' socioeconomic status or comorbidities, as it was not possible to study their influence on clinical outcomes.

This study is the first to our knowledge to describe the temporal trend of LRTIs in Spain during 22 years, including both pneumonia and acute bronchitis/bronchiolitis. Conditions of the hospitalized patients and the clinical results were analysed, also differentiating by the specific clinical diagnosis leading to the hospitalization. The study revealed that LRTIs are a growing problem in Spain, with important consequences for the patients' morbi-mortality. It is also important to note that this clinical condition has a greater impact on people at both extremes of the age range, a vulnerable population that needs special protection. The current COVID-19 pandemic has abruptly increased the incidence of hospitalizations and the mortality rate related to respiratory infectious diseases, and our study may con- stitute the baseline on which to compare the situation in forthcoming years.

In conclusion, LRTIs have a relevant impact on both morbidity and mortality in Spain. There is an upward trend in hospitalizations and deaths related to LRTIs over time, being both higher for pneumonia than for acute bronchitis/bronchiolitis. Hospitalizations due to pneumonia occurred mainly in people over 74 years and hospitalizations due to acute bronchitis/bronchiolitis in children under one year. Mortality predominantly affected people over 74 years of age. Intensification of measures and specific interventions are needed to reduce the burden of LRTIs, particularly for people at higher risk of suffering complications.

\section{Acknowledgements}

Special thanks to the Health Information General Sub-Directorate of the Ministry of Health, Consumer Affairs and Social Welfare of the Spanish Government for making data publicly accessible.

\section{REFERENCES}

1. GBD 2016 Lower Respiratory Infections Collaborators. Estimates of the global, regional, and national morbidity, mortality, and aetiologies of lower respiratory infections in 195 countries, 1990-2016: a systematic analysis for the Global Burden of Disease Study 2016. Lancet Infect Dis 2018; 18: 1191-1210. https://doi.org/10.1016/ S1473-3099(18)30310-4

2. GBD 2017 Causes of Death Collaborators. Global, regional, and national age-sex specific mortality for 282 causes of death in 195 countries and territories, 1980-2017: A systematic analysis for the Global Burden of Disease Study 2017. Lancet 2018; 392: 1736-1788. https://doi.org/10.1016/ S0140-6736(18)32203-7

3. Toledo D, Soldevila N, Torner N, Pérez-Lozano MJ, ESPEJO E, NAVARRO G et al. Factors associated with 30-day readmission after hospitalisation for community-acquired pneumonia in older patients: a cross-sectional study in seven Spanish regions. BMJ Open 2018; 8: e020243. https://doi. org/10.1136/bmjopen-2017-020243

4. Sanz F, Morales-Suárez-Varela M, Fernández E, Force L, PÉrez-Lozano MJ, Martín V et al. A composite of functional status and pneumonia severity index improves the prediction of pneumonia mortality in older patients. J Gen Intern Med 2018; 33: 437444. https://doi.org/10.1007/s11606-017-4267-8 
5. DE Miguel-Díez J, JimÉnEZ-García R, HernáNDEZ-BarRera V, Jiménez-Trujlllo I, DE Miguel-Yanes JM, MÉndeZBAILÓN M et al. Trends in hospitalizations for community-acquired pneumonia in Spain: 2004 to 2013. Eur J Intern Med 2017; 40: 64-71. https:// doi.org/10.1016/j.ejim.2016.12.010

6. Polverino E, Torres A, Menendez R, Cillóniz C, VALLes JM, CAPelastegui A et al. Microbial aetiology of healthcare associated pneumonia in Spain: a prospective, multicentre, case-control study. Thorax 2013; 68: 1007-1014. https://doi. org/10.1136/thoraxjnl-2013-203828

7. Saiz LC, GarJón J, Gorricho J, Erviti J, GiL-García MJ, Martín-Merino E. Validation and incidence of community-acquired pneumonia in patients with type 2 diabetes in the BIFAP Database. Epidemiol Infect 2017; 145: 3056-3064. https://doi.org/10.1017/ S0950268817001868

8. Subdirección General de Información Sanitaria. Ministerio de Sanidad, Consumo y Bienestar Social del Gobierno de España. Conjunto Mínimo Básico de Datos-Hospitalización (CMBD-H). Registro de Actividad de Atención Especializada (RAE-CMBD). [Accessed February 14, 2021]. https://pestadistico.inteligenciadegestion. mscbs.es/PUBLICOSNS/Comun/ArbolNodos. aspx?idNodo $=23525$

9. Subdirección General de Información Sanitaria e Innovación. Dirección General de Salud Pública, Calidad e Innovación. Ministerio de Sanidad, Consumo y Bienestar Social del Gobierno de España. eCIE9MC. Edición electrónica de la CIE-9-MC. $9^{\mathrm{a}}$ Revisión, modificación clínica, [Accessed October 21, 2019]. https://eciemaps.mscbs.gob.es/ ecieMaps/browser/index_9_mc.html; 2014

10. Subdirección General de Información Sanitaria e Innovación. Dirección General de Salud Pública, Calidad e Innovación. Ministerio de Sanidad, Consumo y Bienestar Social del Gobierno de España. eCIE10ES. Edición electrónica de la CIE-10-ES. $2^{\text {a }}$ edición. [Accessed October 21, 2019]. https:// eciemaps.mscbs.gob.es/ecieMaps/browser/metabuscador.html; 2018

11. Welte T, Torres A, Nathwani D. Clinical and economic burden of community-acquired pneumonia among adults in Europe. Thorax 2012; 67: 71-79. https://doi.org/10.1136/thx.2009.129502

12. Torres A, Peetermans WE, Viegi G, Blasi F. Risk factors for community-acquired pneumonia in adults in Europe: a literature review. Thorax 2013; 68: 1057-1065. https://doi.org/10.1136/thoraxjnl-2013-204282

13. The Institute for Health Metrics and Evaluation. University of Washington (USA). Global Burden Disease (GBD) Compare - Viz Hub. [Accessed February 19, 2021]. https://vizhub.healthdata.org/ gbd-compare/

14. Li G, Cook DJ, Thabane L, Friedrich JO, Crozier TM, MusCEDERE $\mathrm{J}$ et al. Risk factors for mortality in patients admitted to intensive care units with pneumonia. Respir Res 2016; 17: 80. https://doi: 10.1186/s12931-016-0397-5
15. Yokoe DS, Anderson DJ, Berenholtz SM, Calfee DP, DubBerke ER, Ellingson KD et al. A compendium of strategies to prevent healthcare-associated infections in acute care hospitals: 2014 updates. Infect Control Hosp Epidemiol 2014; 35: 967-977. https://doi.org/10.1086/677216

16. Tablan OC, Anderson LJ, Besser R, Bridges C, HajJeH R; CDC; Healthcare Infection Control Practices Advisory Committee. Guidelines for preventing health-care-associated pneumonia, 2003: recommendations of CDC and the Healthcare Infection Control Practices Advisory Committee. MMWR Recomm Rep 2004; 53: 1-36

17. Kalil AC, Metersky ML, Klompas M, Muscedere J, SweEnEy DA, PALMER LB et al. Management of adults with hospital-acquired and ventilator-associated pneumonia: 2016 clinical practice guidelines by the Infectious Diseases Society of America and the American Thoracic Society. Clin Infect Dis 2016; 63: e61-e111. https://doi.org/10.1093/cid/ciw353

18. Torres A, Niederman MS, Chastre J, Ewig S, FernandeZVANDEllos P, Hanberger $\mathrm{H}$ et al. International ERS/ ESICM/ESCMID/ALAT guidelines for the management of hospital-acquired pneumonia and ventilator-associated pneumonia: Guidelines for the management of hospital-acquired pneumonia (HAP)/ ventilator-associated pneumonia (VAP) of the European Respiratory Society (ERS), European Society of Intensive Care Medicine (ESICM), European Society of Clinical Microbiology and Infectious Diseases (ESCMID) and Asociación Latinoamericana del Tórax (ALAT). Eur Respir J 2017; 50: 1700582. https://doi.org/10.1183/13993003.00582-2017

19. Sinuff T, Muscedere J, Cook DJ, Dodek PM, ANDERSON W, KEENAN SP et al. Implementation of clinical practice guidelines for ventilator-associated pneumonia: a multicenter prospective study. Crit Care Med 2013; 41: 15-23. https://doi.org/10.1097/ CCM.0b013e318265e874

20. Berenholtz SM, Pham JC, Thompson DA, NeEdham DM, LuBomski LH, Hyzy RC et al. Collaborative cohort study of an intervention to reduce ventilatorassociated pneumonia in the intensive care unit. Infect Control Hosp Epidemiol 2011; 32: 305-314. https://doi.org/10.1086/658938

21. Eom JS, Lee MS, Chun HK, Chor HJ, Jung SY, Kim YS et al. The impact of a ventilator bundle on preventing ventilator-associated pneumonia: a multicenter study. Am J Infect Control 2014; 42: 34-37. https://doi.org/10.1016/j.ajic.2013.06.023

22. Állvarez Lerma F, Sánchez García M, Lorente L, Gordo F, AÑón JM, ÁlvAREZ J et al. Guidelines for the prevention of ventilator-associated pneumonia and their implementation. The Spanish "Zero-VAP" bundle. Med Intensiva 2014; 38: 226-236. https:// doi.org/10.1016/j.medin.2013.12.007

23. Áldvarez-Lerma F, Palomar-Martínez M, Sánchez-García M, Martínez-Alonso M, Álvarez-Rodríguez J, LorenTE L et al. Prevention of ventilator-associated pneumonia: the multimodal approach of the Spanish ICU "Pneumonia Zero" program. Crit Care Med 2018; 46: 181-188. https://doi.org/10.1097/ CCM.0000000000002736 


\section{APPENDIX 1. Internal Classification of Diseases (ICD) codes for lower respiratory tract infections (LRTIs) ${ }^{a}$}

\begin{tabular}{c|c|l}
\hline Classification & Code & Description \\
\hline \multirow{3}{*}{ ICD-9 $^{\text {b }}$} & 466 & Acute bronchitis and bronchiolitis \\
& 480 & Viral pneumonia \\
& 481 & Pneumococcal pneumonia [Streptococcus pneumoniae pneumonia] \\
& 483 & Other bacterial pneumonia \\
& 484 & Pneumonia due to other specified organism \\
& 485 & Preumonia in infectious diseases classified elsewhere \\
& 486 & Pneumonia, organism unspecified \\
\hline \multirow{3}{*}{ ICD-10 $^{\text {c }}$} & J12 & Viral pneumonia, not classified elsewhere \\
& J13 & Pneumonia due to Streptococcus pneumoniae \\
& J14 & Pneumonia due to Haemophilus influenzae \\
& J15 & Bacterial pneumonia, not classified elsewhere \\
& J16 & Pneumonia due to other infectious organisms, not classified elsewhere \\
& J18 & Pneumonia in diseases classified elsewhere \\
& J20 & Pneumonia, organism unspecified \\
& J21 & Acute bronchitis \\
\hline
\end{tabular}

a: specific diagnostic codes for influenza virus with associated pneumonia were not included, as the information system does not allow data extraction at that level of disaggregation; b: for hospitalizations between 1997-2015; c: for hospitalizations between 2016-2018.

\section{APPENDIX 2. Distribution of hospitalizations according to the diagnostic category} (primary or secondary)

\begin{tabular}{|c|c|c|}
\hline & \multicolumn{2}{|c|}{ Hospitalizations with LRTIs as diagnosis } \\
\hline & Primary or secondary & Primary \\
\hline $\mathbf{N}(\%)$ & $4,348,556(100)$ & $2,952,336(67.9)$ \\
\hline \multicolumn{3}{|c|}{ Hospitalizations by main hospitalization cause, $\%$} \\
\hline Pneumonia & 68.8 & 70.6 \\
\hline Acute bronchitis/bronchiolitis & 31.2 & 29.4 \\
\hline \multicolumn{3}{|l|}{ Sex, \% } \\
\hline Male & 57.8 & 57.3 \\
\hline Female & 42.2 & 42.7 \\
\hline \multicolumn{3}{|l|}{ Age, $\%$} \\
\hline$\leq 74$ years & 57.0 & 58.8 \\
\hline$>74$ years & 43.0 & 41.2 \\
\hline
\end{tabular}


APPENDIX 3. Hospitalizations and mortality due to lower respiratory tract infections (LRTIs) in children under 5 years

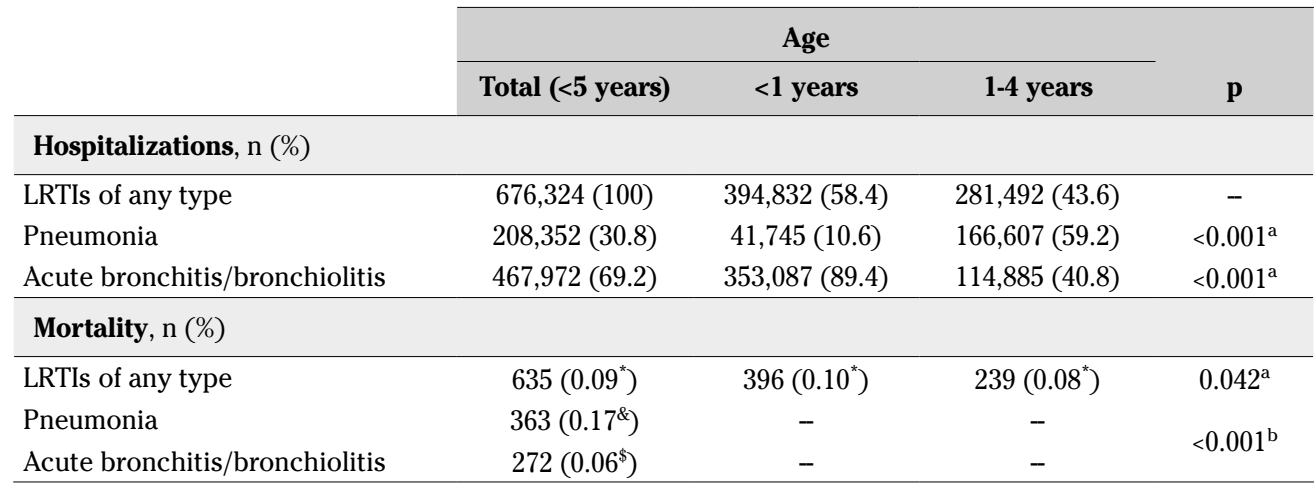

a: comparison by age; b: comparison by type of LRTI; *: \% of total hospitalizations; \&: \% of hospitalizations due to pneumonia; $\$$ : \% of hospitalizations due to acute bronchitis/bronchiolitis. 